\title{
THE PRICE PUZZLE AND THE ROLE OF SOUTH AFRICAN MONETARY POLICY IN BOTSWANA AND NAMIBIA
}

\author{
Philippe Burger* \\ University of the Free State \\ burgerp@ufs.ac.za \\ Helvi Fillipus\# \\ University of the Free State \\ Innocent Molalapata+ \\ University of the Free State
}

March 2011

\begin{abstract}
Using SVAR analysis, this paper finds what Sims calls a 'price puzzle', i.e. a case where CPI increases after a positive interest rate shock. The SVAR analysis controls for various monetary transmission mechanisms, including one based on the South African dominance hypothesis that links South African monetary policy to inflation in Botswana and Namibia. The paper follows Castelnuovo and Surico and interprets the price puzzle as a symptom of an indeterminate monetary policy. Subsequently the paper explores the finding of indeterminate monetary policy further by using an unstructured VAR to estimate the monetary reaction functions of Botswana and Namibia. These results also point to the presence of an indeterminate monetary policy. Lastly, both the SVAR and the unstructured VAR estimated for the monetary reaction function indicate the importance of the exchange rate, and not the interest rate, as a determinant of inflation in both Botswana and Namibia
\end{abstract}

Keywords

Price puzzle, determinate and indeterminate monetary policy, monetary transmission mechanisms

*Prof Philippe Burger is professor at the Department of Economics, University of the Free State, South Africa.

\#Ms Helvi Filllipus was at the time of writing a postgraduate student at the Department of Economics, University of the Free State, South Africa

+Mr Innocent Molalapata was at the time of writing a postgraduate student at the Department of Economics, University of the Free State, South Africa. 


\section{INTRODUCTION}

The South African Reserve Bank (SARB) follows a prudent and reactive anti-inflationary monetary policy. Since the late 1990s this policy has led to much lower inflation in South Africa, and also, due to their dependence on the South African economy, lower inflation in Botswana and Namibia. This statement is very much the conventional understanding of South African monetary policy and its effect since the late 1990s. The question, though, is whether the conventional understanding is correct. Therefore, given the presumed dependence of the Botswana and Namibian economies on the South African economy, this paper investigates the impact of South African monetary policy (relative to the impact of the Botswana and Namibian monetary policies) on the Botswana and Namibian economies. Monetary policy changes are taken as being encapsulated in movements in the policy rate used by either the Botswana and Namibian or the South African central bank. Using Structural Vector Autoregression (SVAR) analysis the paper demonstrates the presence of what Sims (1992) called a "price puzzle". The SVAR analysis takes account of the different possible monetary transmission mechanisms in addition to the core model that includes the nominal interest rate and the logs of CPI and real GDP. The price puzzle is a phenomenon where inflation increases following an increase in the nominal policy interest rate. The existence of the price puzzle, and thus an increase in inflation following an increase in the nominal interest rate, may in principle erode the credibility of a monetary policy that uses an interest rate instrument to contain inflation - hence the need to consider its presence. However, as will be argued below, the presence of a price puzzle is not seen as a phenomenon that is present in a credible and effective monetary policy, but rather as a phenomenon that results from an indeterminate monetary policy, which in principle is a monetary policy that should lack credibility.

Using the SVAR the paper also asks whether the price puzzle results from national monetary policy in Botswana and Namibia or from the spill-over effect of South African monetary policy. In addition to finding a price puzzle, the SVAR estimates show the exchange rate to be an important explanatory variable of the price level in both Botswana and Namibia.

Castelnuovo and Surico $(2006 ; 2009)$ argue that a price puzzle only appears when monetary policy is indeterminate, i.e. when the nominal interest rate does not increase by more than the increase in the inflation rate, thereby causing the real interest rate to decrease. The paper further explores this lead provided by Castelnuovo and Surico $(2006$; 2009) by presenting monetary reaction functions estimated within an unstructured VAR context. This VAR includes the real interest rate, inflation, economic growth and the log of the real effective exchange rate. In the equations of the VARs that represent the monetary reaction functions estimated for Botswana and Namibia the exchange rate has, contrary to a priori expectations, a positive effect as measured through the impulse response function. This positive effect is only possible if the central bank pursues an indeterminate monetary policy. This finding then corresponds with the presence of a price puzzle found in the SVAR estimates and as such confirms the suspicion that monetary policy is indeterminate.

Thus, in exploring the price puzzle, the paper focuses on the following issues:

- The impact of South African monetary policy on the economies of Botswana and Namibia, and more specifically their inflation rates. Given the dependence of these two economies on South Africa, it might be no surprise that an imported inflation effect is prevalent and that monetary policy developments in South Africa may spill over to both Botswana and Namibia. 
- The impact on inflation of national monetary policy after controlling for the influence of South African monetary policy.

- The degree of monetary policy subordination and the validity of the South African Dominance (SAD) hypothesis with respect to monetary policy.

- The impact of domestic inflation, economic growth and the exchange rate on national monetary policy, i.e. the role of these variables in the monetary reaction functions of Botswana and Namibia.

\section{THE PRICE PUZZLE}

SVAR models are a popular tool for analysing the effects of monetary policy on the aggregate economy through various channels. However, it is the empirical literature using SVAR analysis that yielded results that seemingly contradicted a priori expectations when it produced what Sims (1992) termed the "price puzzle". The price puzzle is a statistically significant positive reaction of the price level to a contractionary monetary policy shock. Sims (1992), who initially diagnosed this anomaly for the United States, Japan, Germany, UK and France, argues that it stems from misspecification of variables within the VAR. A substantial portion of the empirical literature on the US economy finds that the price puzzle is associated primarily with the 1959-79 sample period, and that attempts to correct specification issues fail to resolve the puzzle over this period (Castelnuovo and Surico, 2009 and Hanson, 2004). Similar results were found for the UK during the pre-inflation targeting era (Castelnuovo \& Surico, 2006), whereas for Germany the price puzzle is mostly prevalent over the pre-1989 sample period (Bernanke \& Mihov, 1997; Clarida \& Gertler, 1996). The puzzle was also diagnosed in emerging markets such as Brazil and Turkey (Cysne, 2004; Aktas et al., 2005).

According to Sims (1992) the price puzzle could result from a failure to include rich enough specifications of the information available to policy makers, and the puzzle could be solved by the inclusion of a commodity price index in the VAR specification. The literature also suggests that the anomaly can be solved by augmenting the VAR with other omitted variables such as the Production Price Index, unit labour cost and M2 growth (see Castelnuovo \& Surico, 2006; Leeper \& Roush, 2003; Sbordone, 2002).

However, Castelnuovo and Surico $(2006 ; 2009)$ incorporated commodity prices, the Production Price Index, unit labour cost and M2 growth into the vector of endogenous variables and found that the price puzzle hypothesis still persists in specific sub-sample periods. They demonstrate that the bias of the SVARs towards a price puzzle is not due to an identification or specification strategy. Rather, the price puzzle phenomenon is prevalent under an indeterminate monetary policy regime. Following a change in inflation in a determinate monetary policy regime, the nominal interest rate is adjusted with more than the change in inflation. As a result the real interest rate would change in the same direction as the nominal interest rate, which in turn will put pressure in the opposite direction on the price level. Under an indeterminate monetary policy regime, the nominal interest rate reacts with less than the change in inflation, causing the real interest rate to decrease (increase) following an increase (decrease) in inflation. The lower (higher) real interest rate spurs (inhibits) further inflationary pressure while it should actually do the opposite (also see Hanson (2004)). Castelnuovo and Surico (2009) argue that the price puzzle stems from spurious correlations under an indeterminate monetary policy regime and can be eliminated through the inclusion of a variable capturing expected inflation. Unfortunately, for Botswana and Namibia there is no expected inflation series that is long enough to be 
included in the analysis. However, whether the price puzzle can be eliminated with the inclusion of expected inflation is not the central question of this paper, as the paper builds on the finding by Castelnuovo and Surico $(2006 ; 2009)$ that the price puzzle only appears in the face of an indeterminate monetary policy. Thus, finding a price puzzle is taken as a symptom of an indeterminate monetary policy.

\section{BACKGROUND ON BOTSWANA AND NAMIBIA}

Botswana left the Rand Monetary Area (now called Common Monetary Area (CMA)) in 1976 and issued its own currency, the Pula, which is pegged to a basket that comprises the South African Rand and the IMF's Special Drawing Rights (SDR), with the weights broadly reflecting trade patterns. The conduct of monetary policy in Botswana is aimed at fostering the stability of the real effective exchange rate, thereby contributing towards Botswana's international competitiveness (Bank of Botswana (BoB), 2008). Namibia has been a member of the CMA since 1990 and introduced the Namibian Dollar in 1993, which is pegged at par to the South African Rand. The primary objective of the Bank of Namibia is to maintain the fixed peg against the Rand and thus import inflation- and output stability from South Africa through maintaining peg credibility (Bank of Namibia (BoN), 2008).

The dominance of South African economic conditions over that of both Botswana and Namibia ensures a high pass-through effect of foreign prices, with imports from South Africa playing a considerable role in determining the inflation trends in the two countries. Imports from South Africa respectively account for approximately $81 \%$ and $85 \%$ of the total imports of Botswana and Namibia (CSO, 2010; Nailenge \& Fleermuys, 2008). Therefore, as FIGURE 1 illustrates, there are parallel movements between inflation rates in the three countries. The deviations in inflation rates to a large extent emerge as a result of technical differences between the consumer price indices (CPIs) of the three countries and movements in administered prices that constitute significant weights in the respective CPIs (Gaomab II, 1999).

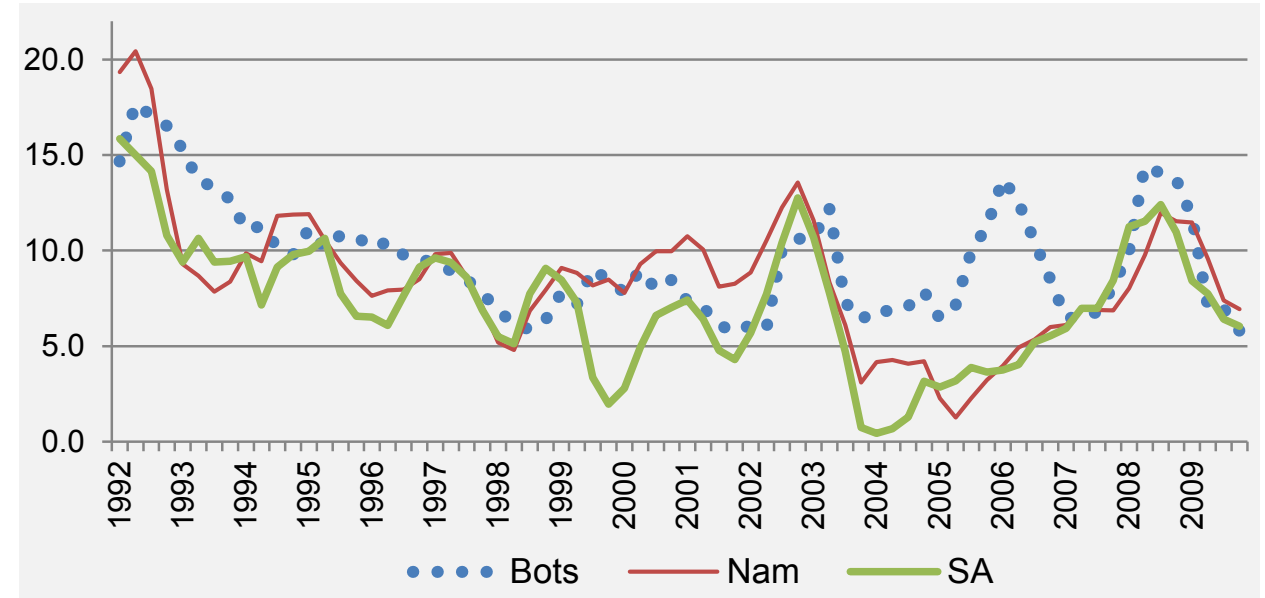

FIGURE 1: Inflation rates

Source: $B O B, B O N, S A R B$

South African dominance and the analogous inflation trends among the three countries 
constitute the rationale to harmonise monetary policy, i.e., there should be a certain degree of interest rate pass-through from the SARB policy rate to the bank rates in the other two countries. In the case of Namibia, an almost full interest-rate pass-through is achieved (see FIGURE 2). The slight divergence between the two rates is attributed to country-specific risk factors that result from the lower quality of prime borrowers in Namibia compared to South Africa. However, with reference to Botswana, the interest-rate pass-through is limited. The domestic policy rate is adjusted in conformity with the performance of a basket of currencies (Kganetsano, 2007). Hence, although the South African currency has a considerable weight in the basket, the performance of the other currencies in the basket also influences the direction of nominal interest rates.

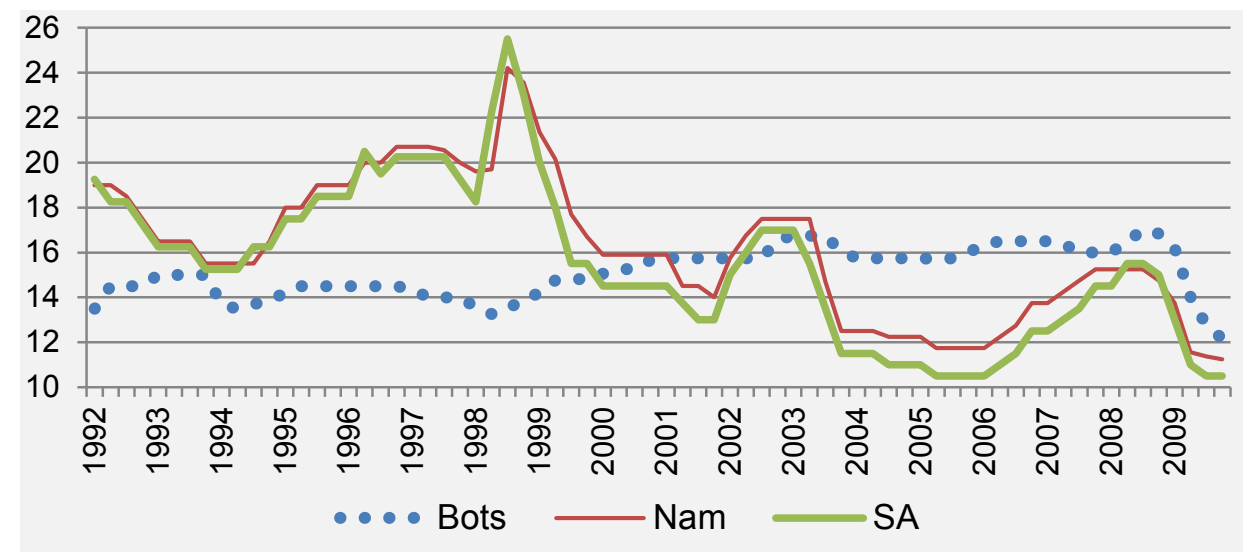

FIGURE 2: Prime lending rates

Source: $B O B, B O N, S A R B$

\section{THE MONETARY TRANSMISSION MECHANISM}

Traditionally, central banks are mandated to carry out monetary policy operations with the ultimate objective of safeguarding price stability and promoting sustainable growth. Naturally, monetary policy does not influence the target variables such as output and inflation directly. Instead monetary policy generates numerous chain reactions that evoke responses in aggregate demand (Mishkin, 1996; Smal \& De Jager, 2001). The literature identifies diverse routes through which the monetary policy stance affects target variables.

As Sun et al. (2010) posited out, the importance and relevance of the various channels are not universal. Rather, they are unique to each economy owing to varying depths of financial systems, economic structures and the range of economic activities. The conduct and transmission of monetary policy innovations in economies that are highly dependent on a dominant trading partner are among some of the unique cases. Namibia as a member of the Common Monetary Area (CMA) does not engage in any active discretionary monetary policy, and has primarily subordinated the conduct of monetary policy to that of the South African Reserve Bank (SARB) (Kalenga, 2001). Botswana pursues a quasi-independent monetary policy, but its currency is informally linked to the Rand through a currency basket in which the latter constitutes a significant weight (Aziakpono, 2008). In light of these arrangements, the conduct of monetary policy in the two countries might be highly influenced by that of South Africa. 
The literature on monetary policy transmission outlines several channels through which these monetary policy actions are transmitted to the real economy. The most common channels include the interest rate channel, the exchange rate channel, the credit channel and the asset price channel.

\subsection{Interest rate channel}

The traditional interest rate channel focuses on the central bank's ability to modify investment spending patterns of the private sector by affecting the real cost of borrowing through changing nominal policy interest rates (Mishkin, 1996; Al-Mashat \& Billmeir, 2007). Empirical studies on the interest rate channel mostly agree on the prevalence of the income effects of monetary policy. However, these effects are not homogeneous across countries. Studies by, among others, Chirinko and Von Kalckreuth (2003), and Morsink and Bayoumi (1999), indicate that the interest rate sensitivity of investment spending is highly significant in developed market economies, while according to Al-Mashat and Billmeier (2007) it is less so in developing economies.

\subsection{The exchange rate channel}

Contractionary (expansionary) monetary policy (a rise (fall) in domestic interest rates) attracts (discourages) foreign capital inflows, thereby putting upward (downward) pressure on the domestic currency. Consequently, the domestic currency appreciates (depreciates). The appreciation (depreciation) reduces (improves) competitiveness and can lead to a fall (rise) in net exports and hence in aggregate output. In addition, an appreciation (depreciation) of the domestic currency also reduces (increases) imported inflation. As Mishkin (2001) argues, the exchange rate channel does not operate if a country has a fixed exchange rate and the more open an economy is, the stronger the channel.

Studies on the exchange rate channel posit that the influence of monetary policy on the exchange rate is limited and highly unpredictable (Bayangos, 2006), and central banks that apply monetary policy rules to the exchange rate (i.e., include the exchange rate in the reaction function) do so with less than satisfactory results (Zams \& Cooray, 2007). Empirical results on African countries, though, indicate a dominant role of exchange rates in establishing inflation and output dynamics in these countries (see Mutoti, 2006; Cheng, 2006; Al-Mashat \& Billmeier, 2007). The reason for pronounced reliance on exchange rate developments for African economies is their small, relatively open structures and reliance on exports of primary products that leave external shocks to be an important driver of output.

\subsection{The credit channel}

The credit channel largely exists because of financial market frictions caused by information asymmetries between lenders and borrowers (Zurlinden, 2005). One component of the credit channel is the bank lending channel that is based on the view that banks play a special role in the financial system, as they are well suited to solve asymmetric information problems in credit markets (Mishkin, 1996). The bank-lending channel theory holds that monetary policy works in part by affecting the supply of loans offered by depository institutions (Bernanke, 2007).

According to Mishkin (1996), as long as there is no perfect substitutability of retail bank deposits with other sources of funds, the bank lending channel of monetary transmission might be effective. Contractionary monetary policy, which decreases bank reserves and bank deposits, 
decreases the quantity of bank loans available. Given banks' special role as lenders to classes of bank borrowers, this decrease in loans will cause investment (and possibly consumption) to decrease. This channel focuses on changes in the financial environment for smaller firms. Smaller firms might be unable to tap financial markets directly and may depend solely on bank borrowing for investment financing. Thus, contractionary monetary policy will exert a disproportionate impact on smaller forms.

Another possible channel for monetary policy transmission is through asset prices. However, due to the South African dominance over the two economies, foreign companies constitute the largest portion of market capitalisation on the Botswana and Namibian stock exchanges. Hence, the overall performance of the two stock exchanges tends to be influenced largely by external developments and to a lesser extent by domestic monetary conditions, so that the asset price channel is dormant.

\section{METHOD}

Following the aforementioned literature, this paper adopts an SVAR method to assess the effectiveness of monetary policy in Botswana and Namibia. Prior to estimating the SVAR models, unit root tests are undertaken to establish the stationarity properties of the variables (TABLE Al in the appendix contains the detail). The VARs were estimated in levels, despite some variables being non-stationary. According to Sims, Stock and Watson (1990), distributions are usually unaffected when data is used in levels, thus making it unnecessary to force the process into stationarity by differencing (also see for example Sims (1992) and Bernanke and Mihov (1997, 1998)). (In addition, cointegration tests were conducted to establish the existence of cointegrating relationships in all the VAR models and in all cases one cointegrating vector was found.))

The specified SVAR model follows in the tradition of Sims (1980). Based on the quantity theory of money, the original Sims (1980) specification is based on a monetary policy using the money supply as policy instrument. However, the specification used in the paper is adjusted and augmented to also include the transmission mechanisms discussed above. In particular, the paper also draws on the Taylor rule literature that assumes that monetary policy does not use the money supply, but rather the policy interest rate to influence the economy (Taylor (1993)). The main purpose of SVAR estimation is to obtain non-recursive orthogonalisation of the error terms for impulse-response analysis. This is an alternative to the recursive Cholesky orthogonalisation and requires the user to impose enough restrictions to identify the orthogonal (structural) components of the error terms. The SVAR model is specified as:

$$
A y_{t}=B x_{t}+u_{t}
$$

where $y_{t}$ is a $k$-element vector of endogenous variables, and $x_{t}$ is a vector containing the lagged values of the endogenous variables. $\mathbf{A}$ and $\mathbf{B}$ are $k \times k$ matrices to be estimated. $u_{t}$ is a vector of serially uncorrelated disturbances that have a zero mean and a variance-co-variance matrix $\sum_{\mu}^{2}$. Following an approach initially proposed by Bernanke and Mihov (1997) and replicated by Becklemans (2005) and Cheng (2006), the paper orders the variables in a VAR in such a way that the target variables (the logs of real GDP and CPI) come before the policy variables. This ensures sluggish response of non-policy variables with respect to contemporaneous shocks in the policy variables (Cheng, 2006). The strategy adopted in the paper is to estimate a baseline monetary model (the interest rate channel) with standard variables and then extend it by incorporating 
different variables that depict other channels of monetary policy transmission. Note that in addition to what most papers do, this paper also considers the impact of monetary policy of what might be a dominant country, on the economy of two other countries. Thus, the paper explores whether the relevant monetary policy to consider for Botswana and Namibia is the South African monetary policy.

For each channel, three VAR models were estimated. These SVARs trace the responses to shocks in models containing (1) only the domestic policy rate, (2) only the South African repo rate and (3) both the domestic and South African rates. The objective of the first SVAR is to assess the effectiveness of domestic policy initiatives in the two countries, while the second SVAR seeks to explore the SAD hypothesis. Combining the two rates in the third VAR enables the paper to assess the effectiveness of monetary policy under the current monetary policy arrangements.

The interest rate channel VAR (Model 1) represents the baseline model that includes the policy rates, CPI, nominal money supply and real GDP. For the second model, the baseline model is augmented with the prime lending rate and private sector credit variables to obtain the credit channel SVAR. For the exchange rate channel (Model 3), the real effective exchange rate indices were incorporated into the standard model. The $A y_{t}$ matrices in the VAR models are ordered as set out below. Note that 'repo' in the left-hand matrices represents either the domestic bank rate or the South African repo rate in models that contain either one or the other. 'SSAR' and 'BR' in the right-hand $A y_{t}$ matrices represent the South African repo rate and the domestic bank rate respectively.

\section{Matrices with either the domestic bank rate or SA repo rate}

\section{Matrices with both the domestic bank rate and SA repo rate}

Model l $\left[\begin{array}{cccc}1 & 0 & 0 & 0 \\ \beta_{21} & 1 & 0 & 0 \\ 0 & 0 & 1 & 0 \\ \beta_{41} & \beta_{42} & \beta_{43} & 1\end{array}\right]\left[\begin{array}{c}G D P \\ C P I \\ \operatorname{Repo} \\ M 2\end{array}\right]$

$$
\left[\begin{array}{ccccc}
1 & 0 & 0 & 0 & 0 \\
\beta_{21} & 1 & 0 & 0 & 0 \\
0 & 0 & 1 & 0 & 0 \\
0 & 0 & \beta_{43} & 1 & 0 \\
\beta_{51} & \beta_{52} & \beta_{53} & \beta_{54} & 1
\end{array}\right]\left[\begin{array}{c}
G D P \\
C P I \\
S A R R \\
B R \\
M 2
\end{array}\right]
$$

$\operatorname{Model} 2\left[\begin{array}{ccccc}1 & 0 & 0 & 0 & 0 \\ \beta_{21} & 1 & 0 & 0 & 0 \\ 0 & 0 & 1 & 0 & 0 \\ 0 & 0 & \beta_{33} & 1 & 0 \\ \beta_{41} & \beta_{42} & \beta_{43} & \beta_{44} & 1\end{array}\right]\left[\begin{array}{c}\text { GDP } \\ \text { CPI } \\ \text { Repo } \\ \text { PRM } \\ \text { CRD }\end{array}\right]\left[\begin{array}{cccccc}1 & 0 & 0 & 0 & 0 & 0 \\ \beta_{21} & 1 & 0 & 0 & 0 & 0 \\ 0 & 0 & 1 & 0 & 0 & 0 \\ 0 & 0 & \beta_{43} & 1 & 0 & 0 \\ 0 & 0 & 0 & \beta_{54} & 1 & 0 \\ \beta_{61} & \beta_{62} & \beta_{63} & \beta_{64} & \beta_{65} & 1\end{array}\right]\left[\begin{array}{c}\text { GDP } \\ \text { CPI } \\ \text { SARR } \\ \text { BR } \\ \text { PRM } \\ \text { CRD }\end{array}\right]$

Model $3\left[\begin{array}{ccccc}1 & 0 & 0 & 0 & 0 \\ \beta_{21} & 1 & 0 & 0 & 0 \\ 0 & 0 & 1 & 0 & 0 \\ 0 & 0 & \beta_{43} & 1 & 0 \\ \beta_{51} & \beta_{52} & \beta_{53} & \beta_{54} & 1\end{array}\right]\left[\begin{array}{c}\text { GDP } \\ \text { CPI } \\ \text { REER } \\ \text { Repo } \\ \text { M2 }\end{array}\right]\left[\begin{array}{cccccc}1 & 0 & 0 & 0 & 0 & 0 \\ \beta_{21} & 1 & 0 & 0 & 0 & 0 \\ 0 & 0 & 1 & 0 & 0 & 0 \\ 0 & 0 & \beta_{43} & 1 & \beta_{45} & 0 \\ 0 & 0 & 0 & 0 & 1 & 0 \\ \beta_{61} & \beta_{62} & \beta_{63} & \beta_{64} & \beta_{65} & 1\end{array}\right]\left[\begin{array}{c}\text { GDP } \\ \text { CPI } \\ \text { REER } \\ \text { BR } \\ \text { SARR } \\ \text { M2 }\end{array}\right]$

\section{MONETARY POLICY AND THE PRICE PUZZLE}

The study covers the periods 1993:03 - 2010:01 for Botswana and 1992:01 - 2009:04 for Namibia, with data sourced from the central Banks of Botswana, Namibia and South Africa. All 
nominal variables except rate variables were transformed into logarithms. (The appendix presents a time series plot of the variables.) To investigate the endogenous relationships between key macroeconomic variables, this section presents the empirical results of the SVAR analysis. The Akaike Information Criteria (AIC) and the Schwarz Information Criterion (SC) were used to select the appropriate lag lengths of the VARs. In both cases the optimal lags were identified to lie between 1 and 3 lags.

TABLE 1 presents a summary of the impulse responses from the SVARs for the channels (a graphical representation of the impulse responses would be too bulky - but they are available from the authors on request). Impulse responses present the response of variables to impulses (shocks) to any one of the variables. One can therefore see whether or not a variable displays a statistically significant reaction to a change in another variable. In TABLE 1 , the signs +, - , 0 stands for a positive, negative and no statistically significant relationship, respectively, whereas $X \rightarrow Y$ indicates the response of $Y$ to a shock in $X$. According to the SAD hypothesis, an increase in the South African repo rate should be associated with a corresponding rise in both the Botswana and the Namibian bank rates. The results show that a shock to the South African repo rate consistently elicits a positive response from the Namibian bank rate as expected $a$ priori, whereas the response of the Botswana bank rate is not statistically significant. This finding rejects the South African monetary policy dominance hypothesis for Botswana while asserting it for Namibia.

For Botswana, two of the three models (i.e. six of the nine models estimated for Botswana) show that $\mathrm{CPI}$ increases following an increase in the bank rate. Thus, there is a price puzzle. This puzzle persists in the interest rate and exchange rate models even after controlling for the effect of the South African repo rate. However, in the credit channel model for Botswana, neither the Botswana bank rate nor the South African repo rate impacts CPI. So even though there is no price puzzle, monetary policy has no impact on inflation. Credit, though, positively impacts and is positively impacted by both CPI and the bank rate (and not GDP), so that only after the inclusion of a credit control variable one might find no co-movement of the bank rate and CPI in Botswana. (Note that for Botswana, domestic credit tends to increase following a positive bank rate shock - indicating the presence of a 'credit puzzle'. Therefore, in these models the price puzzle is merely reflected in a credit puzzle whereby credit, and not domestic prices, increases subsequent to a rise in the bank rate. The response of credit to a hike in the prime lending rate becomes negative and significant only after eleven quarters. Kganetsano (2007:145) argues that "the Botswana Government's financial assistance schemes may be undermining the role of commercial banks in credit allocation". That is, even if interest rates are increased, some borrowers who may have been rejected by commercial banks get the funds at subsidised rates from government financial schemes.)

Thus, what is clear in all the models is that CPI does not react negatively to a bank/repo rate change, and in many it reacts positively. Also, the South African repo rate does not impact CPI (or any other variable) in any of the Botswana models, thus confirming the absence of the SAD hypothesis in Botswana so far as monetary policy is concerned. For Namibia the price puzzle is present in the credit channel model that contains only the Namibian bank rate. In the interest rate model containing only the Namibian bank rate, the bank rate has no effect, while in the credit channel and interest rate models containing only the South African repo rate, the price puzzle is present - i.e. CPI increases following an increase in the South African repo rate. When both the Namibian bank rate and the South African repo rate are included in the interest rate and credit channel models, the price puzzle disappears for the Namibian bank rate (the impulse 
response is negative), though the price puzzle is present for the South African repo rate.

In the exchange rate model for Namibia the price puzzle is absent when only the Namibian bank rate or South African repo rate is included. However, it returns for the Namibian bank rate while it seems not present for the South African repo rate if both the Namibian bank rate and South African repo rate are included. Thus, in models containing both the South African and Namibian rates, the price puzzle is associated with the South African repo rate if the model does not control for the exchange rate (with the Namibian rate eliciting a negative CPI effect), while it is associated with the Namibian bank rate if the model controls for the exchange rate.

In both Botswana and Namibia an appreciation of the currency (i.e. an increase in the real effective exchange rate) results in downward pressure on the CPI - thus, being in line with $a$ priori expectations. What is also of interest is that the effect of the South African repo rate on the Namibian CPI disappears when the real effective exchange rate of the Rand is controlled for, indicating that instead of South African monetary policy affecting the CPI, inflation is driven by changes in the exchange rate. Given the role of the exchange rate in the models for both countries, the role of the exchange rate is a subject worth exploring further.

Therefore, to conclude, in both the case of Botswana and Namibia the evidence points towards the presence of an indeterminate monetary policy, be that monetary policy the national monetary policy, as in the case of Botswana, or either the South African or Namibian monetary policy in the case of Namibia. Therefore, the on-going practice of monetary policy in both countries does not fully conform to the stipulations of the monetary policy Taylor rule.

\section{INFLATION VS. THE EXCHANGE RATE AS DETERMINANTS IN THE BOTSWANA AND NAMIBIAN MONETARY REACTION FUNCTIONS}

From the endogenous relationships established in the SVAR analysis above, it emerged that a subdued relationship exists between the monetary policy rate and the price level. The identified price puzzle is commonly found in monetary models in the literature (see Castelnuovo \& Surico, 2006; Hanson, 2004). A question then naturally arises as to what the ultimate factor that drives price behaviour in the two economies is. Going back to the SVAR results, exchange rate movements stood out as a subject for further exploration. This section seeks to follow this lead and investigate the relationship between price developments, the exchange rate and the real interest rate.

A simple cross-correlation analysis indicates that for both Namibia and Botswana the real interest rate and inflation rate are inversely related for the first three quarters, with inflation being the lead variable. This may imply that nominal interest rates are not adjusted to fully compensate for inflationary pressures so that real interest rates move in the opposite direction to inflation. The inverse relationship, in turn, may give rise to the price puzzle. The correct positive relationship between the real interest rate and the inflation rate is realised from the fourth quarter onwards, implying that monetary policy reacts with a lag. 


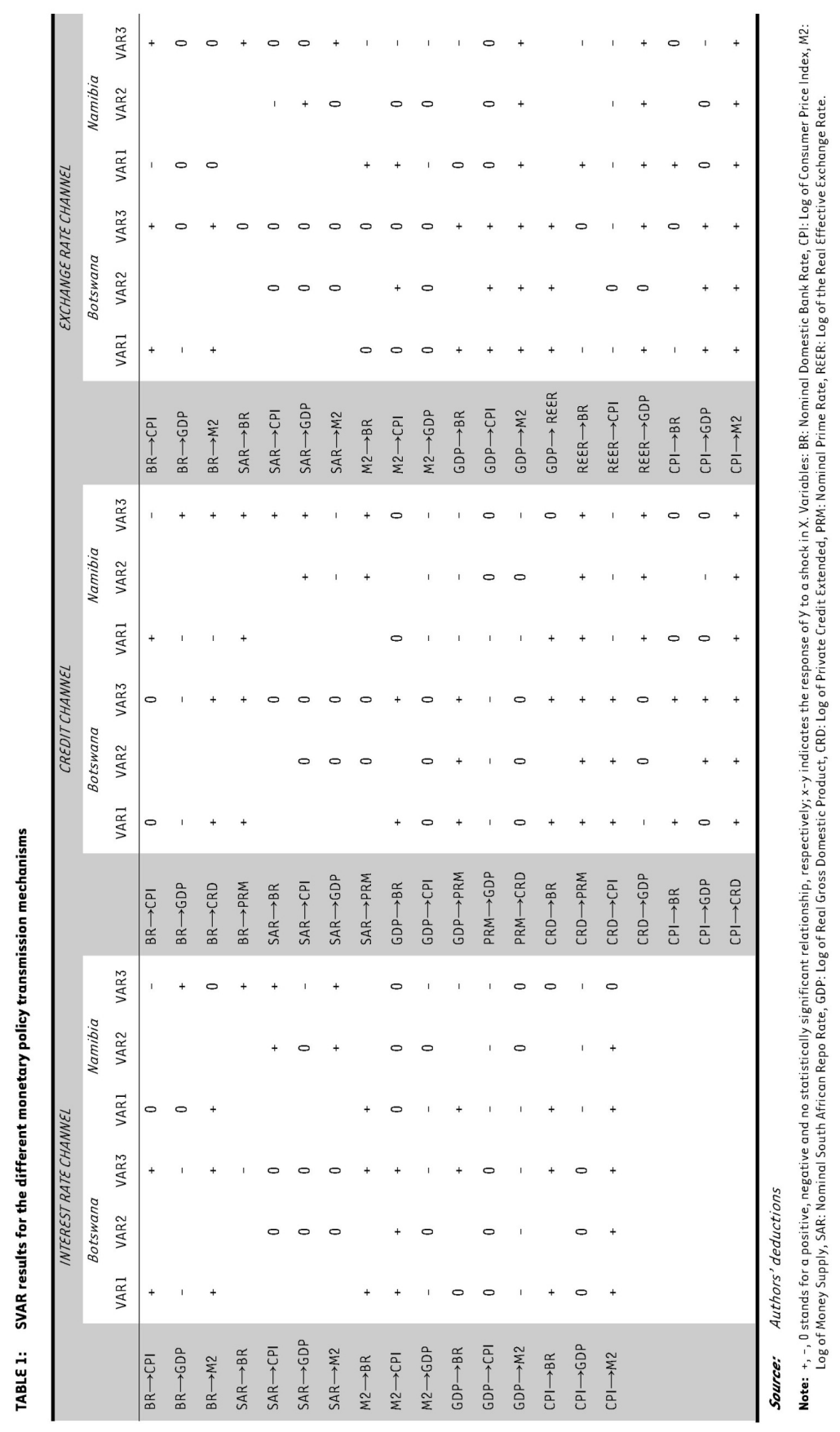


Nonetheless, the correlation coefficient still remains small. Further, correlation analysis reveals a consistent strong negative relationship between the real effective exchange rate and inflation in the two countries. These observations suggest that the external values of the two currencies (i.e. the Botswana Pula and the South African Rand/Namibian Dollar) might be integral in determining domestic price stability.

In terms of economic theory, a currency appreciation (depreciation) leads to lower (higher) prices in the domestic market, thus a lower (higher) inflation rate. If the monetary policy regime follows the Taylor rule (i.e. a case of determinate monetary policy where the real interest rate moves in the same direction as inflation), this fall (rise) in the inflation rate should induce a reduction (an increase) in the nominal interest rate so that on balance real interest rates also decrease (increase). However, with an indeterminate monetary policy, i.e., one that violates the Taylor condition, an appreciation (depreciation) of the domestic currency results in a decline (an increase) in the domestic price level, followed by a central bank that does not lower (raise) nominal interest rates sufficiently, so that real interest rates rise (fall) instead of fall (rise). This spurs further deflationary (inflationary) pressure and results in a positive relationship between local currency movements and the real interest rate (to accompany the price puzzle highlighted above).

The relationship between real interest rates and the exchange rate for Botswana and Namibia will be tested using a simplified monetary policy Taylor rule relationship. The standard Taylor rule is given by:

$$
R_{t}=\left(1-c_{3}\right)\left\{r^{*}+E_{t}\left(\pi_{t+1}\right)+c_{1} X_{t-1}+c_{2}\left(\pi_{t-1}-\pi^{T}\right)\right\}+c_{3} R_{t-1}
$$

where $R$ is the nominal interest rate, $r^{\star}$ is the real equilibrium interest rate (i.e., the rate of interest consistent with a zero output gap), $X$ is an output measure, $\pi$ is the inflation rate, and $\Pi^{\top}$, is the target inflation rate. From this rule, the nominal interest rate is based on expected inflation, a measure of aggregate output, the deviation of inflation from its target and the equilibrium real rate of interest. Given the openness of these economies, one could postulate that the exchange rate is a direct/indirect determinant of monetary policy actions.

Taylor (2001) argued against the inclusion of the exchange rate. More specifically, he argued that the exchange rate is an upstream variable that might influence inflation and output, so that the inclusion of inflation and output in a Taylor rule already accounts for the impact of the exchange rate on the economy and monetary policy. However, the inclusion of the exchange rate controls for the effects of the exchange rate on monetary policy decisions, whether directly or indirectly. Thus, with the inclusion of the exchange rate the parameters on inflation and output will indicate the effect of inflation and output on monetary policy decisions over and above the effect of the exchange rate. Similar research questions were addressed in studies by Ball (1999), Taylor (1999) and Svensson (2000), who extended the closed economy optimal Taylor rule to examine exchange rate implications in open economies.

To control for the endogenous relationships between the variables this paper estimates a monetary reaction function in an unstructured VAR context (i.e. one of the equations in the VAR resembles a monetary reaction function). The VAR also includes the exchange rate together with the inflation rate and output growth. In addition, the VAR uses a real interest rate so that the sign of the inflation rate can give a clear indication of whether or not monetary policy is determinate (a negative sign indicates an indeterminate monetary policy). Thus, the monetary reaction function equation of the VAR is specified as:

$$
r_{t}=c+\sum_{k=1}^{n} \varphi_{t-k} e_{t-k}+\sum_{k=1}^{n} \alpha_{t-k} \Delta y_{t-k}+\sum_{k=1}^{n} \beta_{t-k} \pi_{t-k}+\varepsilon_{t}
$$


where $r$ is the real interest rate, $e$ is the real exchange rate (an increase in e is appreciation of the domestic currency), $\Delta y$ is the real GDP growth rate and $\pi$ is the inflation. The parameters are $\varphi, \alpha$, and $\beta$ and they capture the response of the real interest rate to changes in the real effective exchange rate, real GDP growth and the inflation rate respectively. The parameters $\alpha$ and $\beta$ should be positive and statistically significant, confirming the effectiveness of monetary policy as outlined in the Taylor rule. An appreciation of the real exchange rate means that foreigners will pay less for one unit of the foreign currency (when they repatriate their interest earnings). Hence, an appreciation should cause the real interest rate to decrease, leaving foreign income in terms of the foreign currency unchanged. Hence one would expect a negative relationship between the real effective exchange rate and the real interest rate (i.e. $\varphi$ is expected to be negative). For both Botswana and Namibia the VAR was run with four lags, with the number of lags based on information criteria. The regression also includes seasonal dummies. The LMF test for autocorrelation indicates no autocorrelation at lags 1 to 5 for both Botswana and Namibia (see TABLE 2).

TABLE 2: LMF test ( $p$-values)

\begin{tabular}{lcc} 
& Botswana & Namibia \\
\hline Lag 1 & 0.10 & 0.50 \\
Lag 2 & 0.33 & 0.39 \\
Lag 3 & 0.14 & 0.28 \\
Lag 4 & 0.45 & 0.20 \\
Lag 5 & 0.10 & 0.28 \\
\hline
\end{tabular}

Source: Authors'calculations

TABLE 3 presents the sum of the parameters of the lags for the monetary reaction function. Because some of the parameters were statistically insignificant, TABLE 3 also presents the sum of the parameters of the lags when subset restrictions are placed on the estimated VAR so as to eliminate statistically insignificant lags.

TABLE 3 shows that in Botswana inflation has a negative effect on the real interest rate, which is contrary to a priori expectations based on the Taylor rule. The sum of parameters also indicates the absence of inertia in interest rate movements in Botswana, with the parameter even being negative, though very small. In Namibia growth and inflation both have a positive effect on the interest rate, which accords with a priori expectations (though the parameter on growth is rather small). The positive parameter for inflation indicates a determinate monetary policy in Namibia, though at 0.17 it is not very large. In addition, the interest rate in Namibia displays a very high degree of inertia, with a parameter of approximately 0.9. In both Botswana and Namibia the exchange rate has a positive effect on the real interest rate, meaning that an appreciation causes the real interest rate to increase. This is contrary to a priori expectations. In Botswana a $10 \%$ appreciation leads to approximately a $1 \%$ increase in the real interest rate, while in Namibia it is a $0.3 \%$ increase in the real interest rate. 
TABLE 3: Sum of parameter values

\begin{tabular}{lcccc}
\hline & Botswana & \multicolumn{2}{c}{ Namibia } \\
No restrictions & $\begin{array}{c}\text { Subset } \\
\text { restrictions }\end{array}$ & No restrictions & $\begin{array}{c}\text { Subset } \\
\text { restrictions }\end{array}$ \\
\hline Growth & 0.034 & -0.001 & 0.054 & 0.072 \\
Inflation & -0.463 & -0.565 & 0.151 & 0.170 \\
Interest rate & -0.006 & -0.058 & 0.893 & 0.913 \\
REER & 0.115 & 0.113 & 0.038 & 0.030 \\
\hline
\end{tabular}

Source: Authors'calculations

The impulse-response functions of the estimated VARs can be used to ascertain the impact of shocks to inflation, growth and the exchange rate on the real interest rate. FIGURES 3 and $\mathbf{4}$ show the impacts of shocks to these variables on the real interest rate. Whereas in Namibia shocks to inflation display the a priori expected positive and statistically significant effect on the real interest rate (lasting about six quarters), no such effect is observed in Botswana. This is in line with the parameters reported for inflation in TABLE 3 . In neither country does growth seem to impact on the real interest rate according to the impulse responses. This also accords with the rather small parameter values for growth reported in TABLE 3.
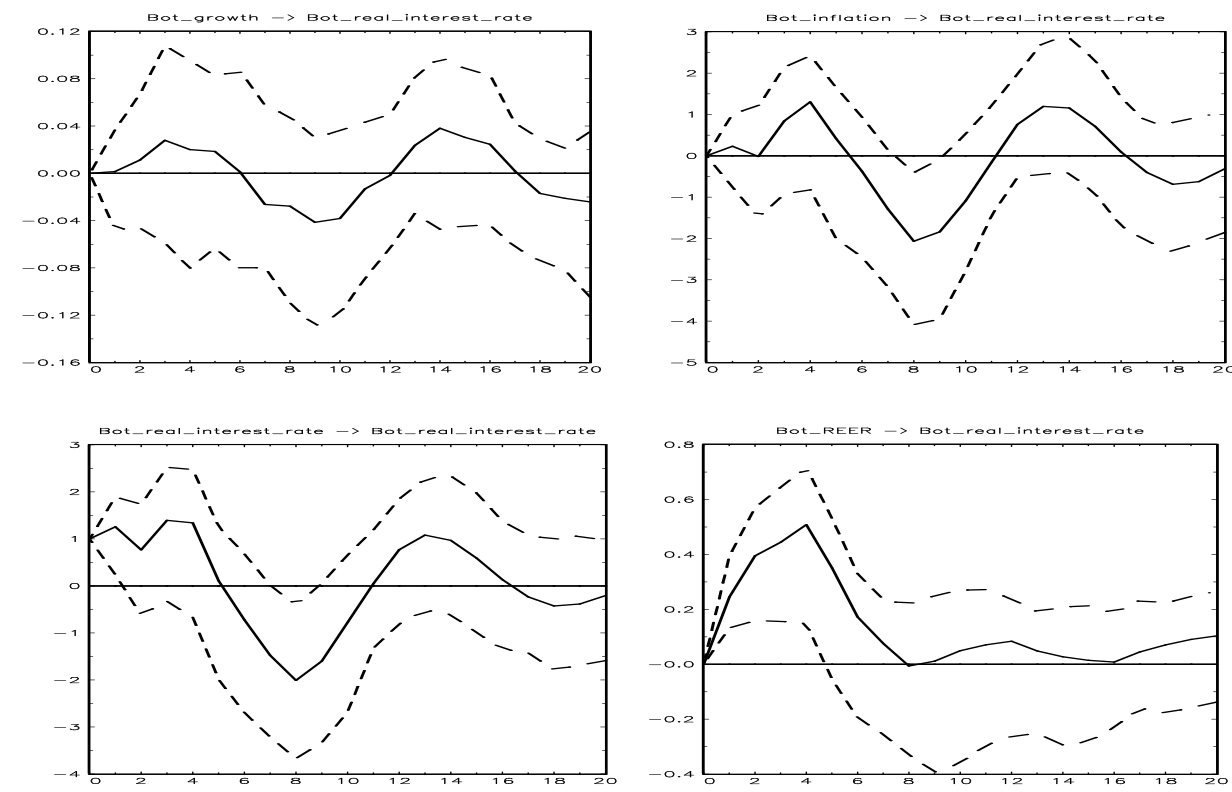

FIGURE 3: Impulse-response functions for Botswana (real interest rate responding)

Source: Authors'calculations 

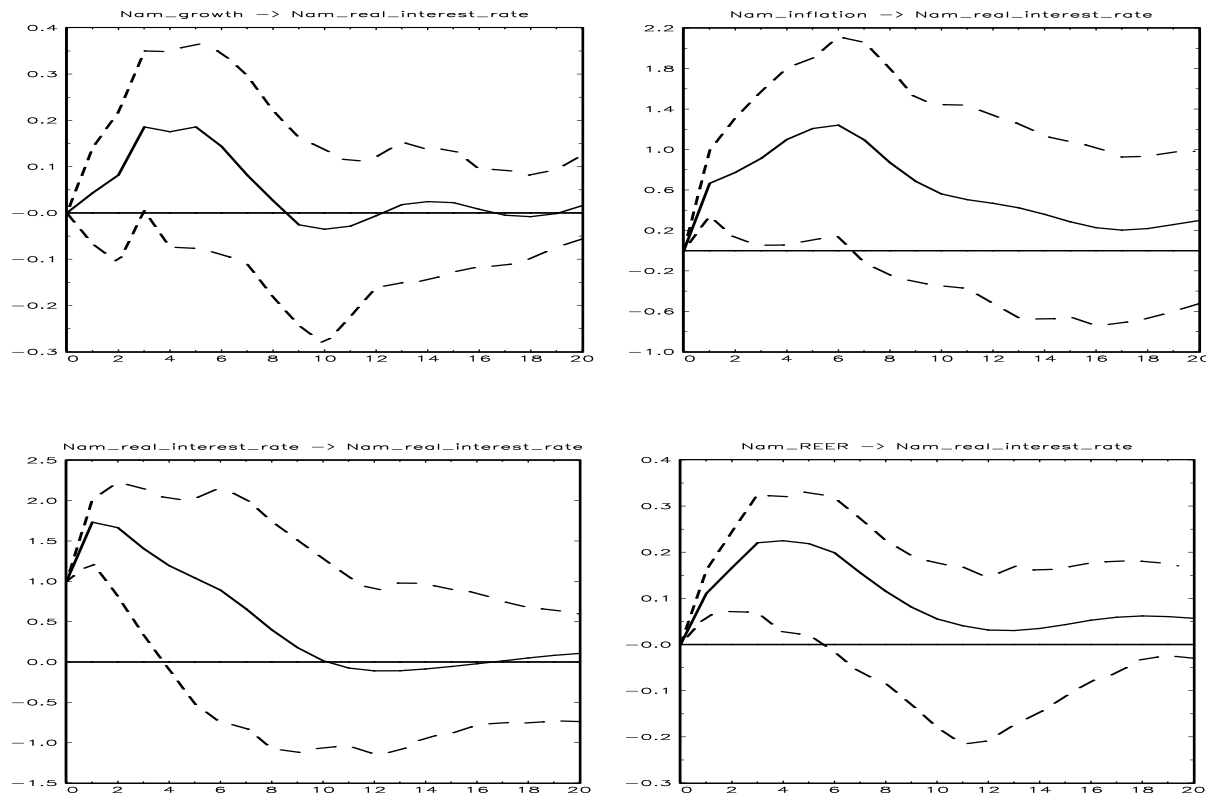

FIGURE 4: Impulse-response functions for Namibia (real interest rate responding)

\section{Source: Authors'calculations}

Furthermore, in both countries the real effective exchange rate has a positive and statistically significant effect on the real interest rate, lasting between four and six quarters (see FIGURE 3 and FIGURE 4).

As mentioned above, an appreciation of the local currency should lead to lower inflation, which in turn, should lead to lower real interest rates. Thus, the relationship found between the real effective exchange rate and the real interest rate contradicts a priori expectations. What does this mean, given that in Namibia, the real interest rate seems to react as expected with respect to inflation, but not as expected with respect to the real exchange rate? Given that exchange rate changes imply changes in purchasing power, the real effective exchange rate should also be seen, like the inflation variable, as a variable representing inflationary pressure. As such, the central bank's reaction to inflation should not only be judged on the basis of its reaction to inflation, but also on the basis of its reaction to the exchange rate. Thus, even though the positive reaction of the real interest rate to inflation accords with the Taylor rule, indicating a determinate monetary policy, the reaction to the exchange rate indicates the contrary. In Botswana the reaction of monetary policy to both inflation and the real effective exchange rate indicates indeterminate monetary policy. 
TABLE 4: Variance decomposition for Botswana

\begin{tabular}{lcccc}
\hline & \multicolumn{4}{c}{ Variation explained by } \\
Variation explained: & Growth & Inflation & Real interest rate & REER \\
\hline Growth & 0.45 & 0.17 & 0.21 & 0.17 \\
Inflation & 0.02 & 0.46 & 0.17 & 0.35 \\
Real interest rate & 0.06 & 0.34 & 0.20 & 0.40 \\
REER & 0.12 & 0.07 & 0.19 & 0.62 \\
\hline
\end{tabular}

Source: Authors'calculations

TABLE 5: Variance decomposition for Namibia

\begin{tabular}{lcccc}
\hline & \multicolumn{4}{c}{ Variation explained by } \\
Variation explained: & Growth & Inflation & Real interest rate & REER \\
\hline Growth & 0.57 & 0.23 & 0.01 & 0.20 \\
Inflation & 0.06 & 0.54 & 0.02 & 0.38 \\
Real interest rate & 0.06 & 0.17 & 0.30 & 0.47 \\
RE\&R & 0.02 & 0.02 & 0.02 & 0.93 \\
\hline
\end{tabular}

Source: Authors'calculations

A variance decomposition can be done to establish the contribution that variations in inflation, the real effective exchange rate and economic growth make to the variation in the real interest rate. In the case of Namibia the contributions of inflation and the real effective exchange rate can also be compared to assess whether the determinate behaviour as captured by the inflation parameter or the indeterminate behaviour as captured by the real effective exchange rate parameter dominates. The variance decomposition of the two VARs (see TABLES $\mathbf{4}$ and $\mathbf{5}$ ) shows that in Botswana and Namibia variations in the real effective exchange rate explain respectively $40 \%$ and $47 \%$ of the variation in the real interest rate, while inflation explains respectively $34 \%$ and $17 \%$. Thus, in both countries variation in the exchange rate explains more of the variation of the real interest rate than variation in inflation. The proportion of variation explained by growth is negligible. Furthermore, note that inflation has a negligible impact on the real effective exchange rate in both countries, as would be expected on a priorigrounds.

Furthermore, note that FIGURE $\mathbf{5}$ shows that in Botswana and Namibia an appreciation of the real effective exchange rate causes a reduction in the inflation rate, while FIGURE $\mathbf{6}$ shows that the real interest rate has no effect on the inflation rate - which accords well with the price puzzle finding in the previous section, where the SVAR was run with the nominal interest rate. These findings furthermore indicate that in both countries monetary policy is indeterminate. In addition, the previous section also shows that the real effective exchange rate is a determinant of the inflation rate, a finding that corresponds with the findings in this section.

Lastly, FIGURE 7 shows that in Botswana an increase in the real interest rate causes the real effective exchange rate to increase (i.e. the domestic currency appreciates), which accords with a priori expectations. FIGURE 7 also shows that an increase in the Namibian real interest rate does not cause an appreciation of the domestic currency, which is to be expected given that the value of the Namibian Dollar is set at par with the South African Rand. 

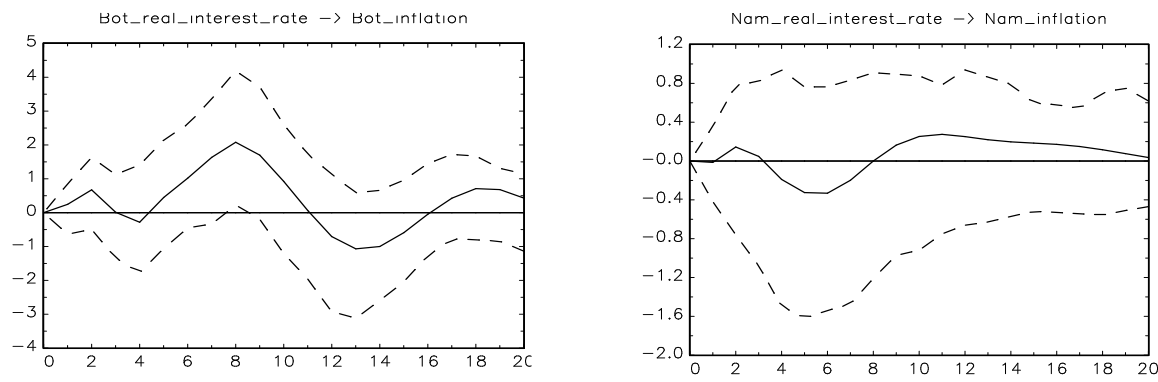

FIGURE 5: Impulse response of the real effective exchange rate on inflation

Source: Authors'calculations
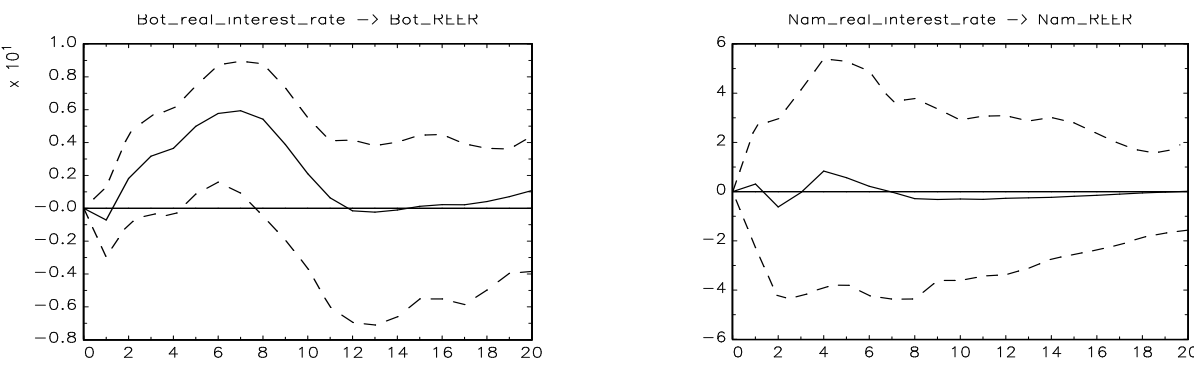

FIGURE 6: Impulse response of the real interest rate on inflation

Source: Authors'calculations
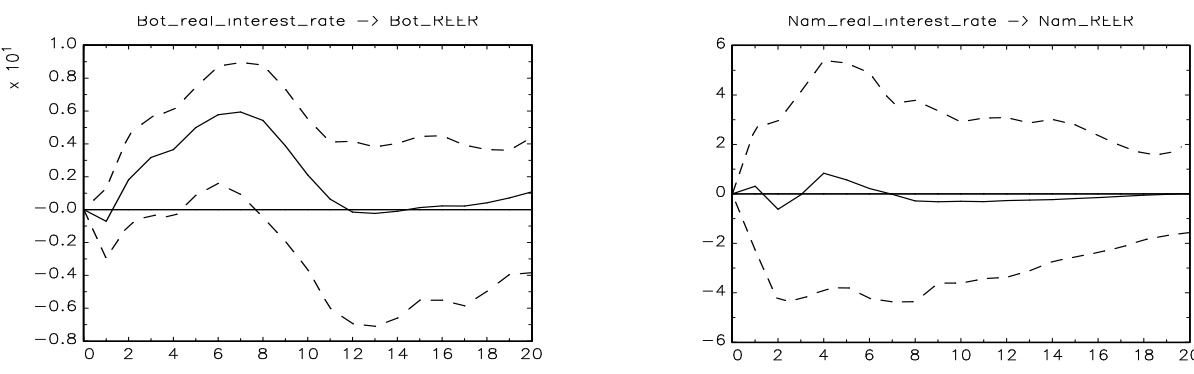

FIGURE 7: Impulse response of the real interest rate on RE\&R

Source: Authors'calculations

\section{CONCLUSION}

In the case of both Botswana and Namibia both the SVAR and unstructured VAR results point towards the presence of an indeterminate monetary policy. More specifically, the SVAR results show that this finding holds whether the monetary policy under discussion is the national monetary policy in the case of Botswana, or either the South African or Namibian monetary 
policy in the case of Namibia. Therefore, neither in Botswana nor in Namibia does monetary policy fully conform to the stipulations of the monetary policy Taylor rule.

Only in the case of Namibia does the South African Dominance (SAD) hypothesis seem to hold with respect to monetary policy. Note that with respect to Botswana this does not mean that the $S A D$ does not hold for other economic variables, only that it seems to be absent with respect to monetary policy.

Lastly, both the SVAR and the unstructured VAR estimated for the monetary reaction function indicate the importance of the exchange rate as a determinant of inflation in both Botswana and Namibia, while the real interest rate seems to have a limited impact, or none at all, on inflation.

\section{LIST OF REFERENCES}

Aktas, B., Kaya, N. \& Ozlale, U. (2005). The Price Puzzle in Emerging Markets: Evidence from the Turkish Economy Using 'Model Based' Risk Premium Derived from Domestic Fundamentals. (Central Bank of the Republic of Turkey, Research Department Working Paper no. 05/02.)

Al-Mashat, R. \& Billmeier, A. (2007). The Monetary Transmission Mechanism in Egypt. (IMF Working Paper 07/285.)

Aziakpono, M. (2008). Financial and Monetary Autonomy and Interdependence between South Africa and the Other SACU Countries. South African Journal of Economics, 76(2), pp. 189-211.

Ball, L. (1999). Policy Rules for Open Economies. In J.B Taylor (ed.) Monetary Policy Rules. Chicago, Illinois: University of Chicago Press (pp. 127-144).

Bank of Botswana. (2008). Annual Report. Gaborone, Botswana.

Bank of Namibia. (2008). Namibia's Monetary Policy Framework. Namibia.

Bayangos, V.B. (2006). Exchange Rate Uncertainty and Monetary Transmission in the Philippines. Institute of Social Studies, Philippines. (Working papers general series number 434).

Becklemans, L. (2005). Credit and Monetary Policy: An Australian SVAR. Reserve Bank of Australia Research: Discussion paper series 2005-06, pp. 1-29.

Bernanke, B. (2007). The Financial Accelerator and the Credit Channel. BIS Review 68/2007.

Bernanke, B. \& Mihov, I. (1997). What does the Bundesbank target? European Economic Review, 41(6), pp. 1025-1053.

Bernanke, B. \& Mihov, I. (1998). Measuring Monetary Policy. The Quarterly Journal of Economics, $113(3)$, pp. 869-902.

Castelnuovo, દ. \& Surico, P. (2006). The Price Puzzle: Fact or Artefact? Bank of England. (Working paper no. 288).

Castelnuovo, E. \& Surico, P. (2009). Monetary Policy, Inflation Expectations and the Price Puzzle. Bank of Finland Research: Discussion paper no. 30.

Cheng, K. (2006). A VAR Analysis of Kenya's Monetary Policy Transmission Mechanism: How Does the Central Bank's REPO Rate Affect the Economy? (IMF working paper no. 06/300). 
Chirinko, R.S. \& Von Kalckreuth, U. (2003). On the German Monetary Transmission Mechanism: Interest Rate and Credit Channels for Investment Spending. (CESifo working paper no. 838).

Clarida, R. \& Gertler, M. (1996). How the Bundesbank conducts Monetary Policy. (NBER working paper no. 5581).

CS0. (2010). Central Statistics Office. [On-line] Available: http://www.cso.gov.bw. (Accessed 27 May 2010)

Cysne, R.N. (2004). Is There a Price Puzzle in Brazil? An Application of Bias-Corrected Bootstrap. Ensaios Economicos, 577.

Gaomab II, M. (1998). Modelling Inflation in Namibia. Bank of Namibia: Occasional paper no. 1.

Hanson, M.S. (2004). The Prize Puzzle reconsidered. Journal of Monetary Economics, 51, pp. 13851413.

Kalenga, P. (2001). Monetary Policy Frame work in Namibia. Conference on Monetary Policy Frameworks in Africa, 17-19 September, South Africa, pp. 227-244.

Kganetsano, T.A. (2007). Transmission of Monetary Policy in Botswana. Unpublished PhD Thesis, Loughborough: Loughborough University.

Leeper, E.M. \& Roush, J. (2003). Putting 'M' back in Monetary Policy. Journal of Money, Credit and Banking, 35(6), pp. 1217-1256.

Mishkin, F.S. (1996). The Channels of Monetary Transmission: Lessons for Monetary Policy. Banque de France Bulletin Digest, 27, pp. 33-44.

Mishkin, F.S. (2001). The Transmission Mechanism and the Role of Asset Prices in Monetary Policy. (NBER Working paper no. 8617).

Morsink, J. \& Bayoumi, T. (1999). The Monetary Transmission Mechanism in Japan. (IMF Working paper no. 99/137).

Mutoti, N. (2006). Monetary Policy Transmission in Zambia. Bank of Zambia. (Working Paper WP/06/2006).

Nailenge, E.P. \& Fleermuys, F. (2008). Developing the Inflation Forecasting Core Model for Namibia: Part A - Monetary Policy Transmission Mechanism for Namibia. Internal Document: Bank of Namibia.

Sbordone, A. (2002). Prices and Unit Labor Costs: A New Test of Price Stickiness. Journal of Monetary Economics, 49, pp. 265-292.

Sims, C. (1980). Macroeconomics and Reality. Econometrica, 48(1), pp. 1-48.

Sims, C. (1992). Interpreting the Macroeconomic Time Series Facts: The effects of monetary policy. European Economic Review, 36, pp. 975-1011.

Sims, C., Stock, J. \& Watson, M. (1990). Inference in Linear Time Series Models with some Unit Roots. Econometrica, 58(1), pp. 113-144.

Smal, M.M. \& De Jager, S. (2001). The Monetary Policy Transmission Mechanism in South Africa. South African Reserve Bank: Occasional paper no. 16.

Sun, L., Ford, J.L. \& Dickinson, D.G. (2010). Bank Loans and the Effects of Monetary Policy in China: VAR/VECM Approach. China Economic Review, 21, pp. 65-97.

Svensson, L.E.0. (2000). Open-Economy Inflation Targeting. Journal of International Economics, 50 (1), pp. 155-183. 
Taylor, J.B. (1993). Discretion versus Policy Rules in Practice. Carnegie-Rochester Conference Series on Public Policy39 (1993), pp. 195-214

Taylor, J.B. (1999). Robustness and Efficiency of Monetary Policy Rules as Guidelines for Interest Rate Setting by the European Central Bank. Journal of Monetary Economics, 43(3), pp. 655-679.

Taylor, J.B. (2001). The Role of the Exchange Rate in Monetary Policy Rules. American Economic Review, AEA Papers and Proceedings, 91 (2), pp. 263-7.

Zams, B.M. \& Cooray, N.S. (2007). Economic Analysis of the Exchange Rate Channel and Monetary Policy Rule: The Case of Indonesia. (GSIR Working Papers, Economic Development \& Policy Series EDP07-1).

Zurlinden, M. (2005). Credit in the Monetary Transmission Mechanism: An Overview of Some Recent Research Using Swiss Data. Swiss National Bank Economic Studies No. 2005-1. 


\section{APPENDIX}

Time series plot of the variables:

\section{Botswana}
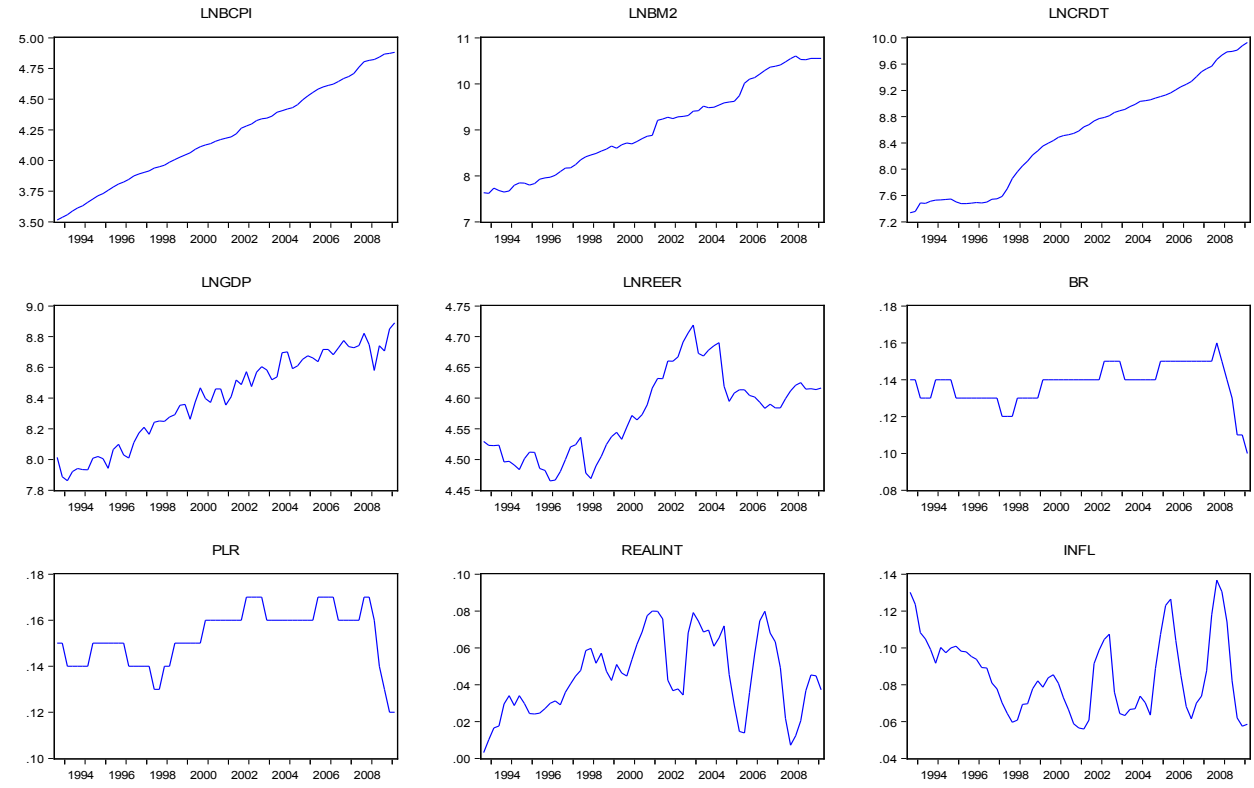

\section{Namibia}
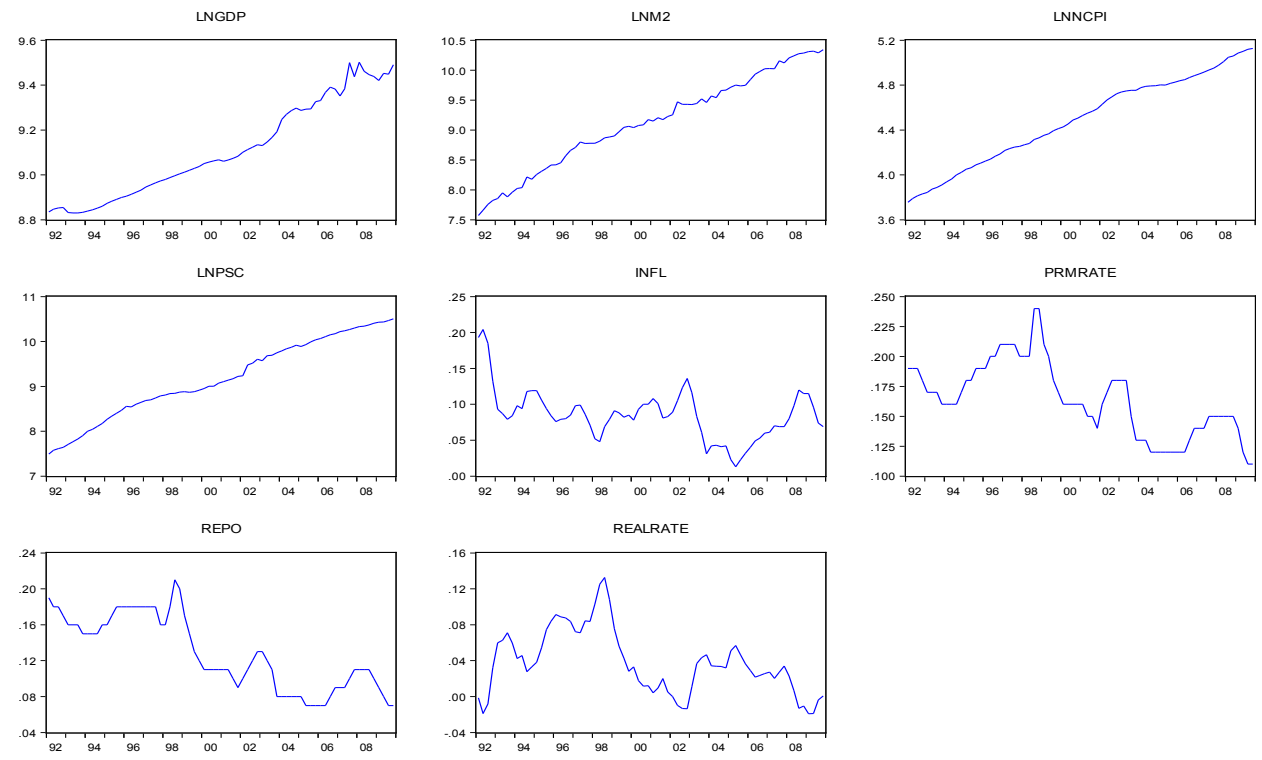


\section{South Africa}

SAREPO

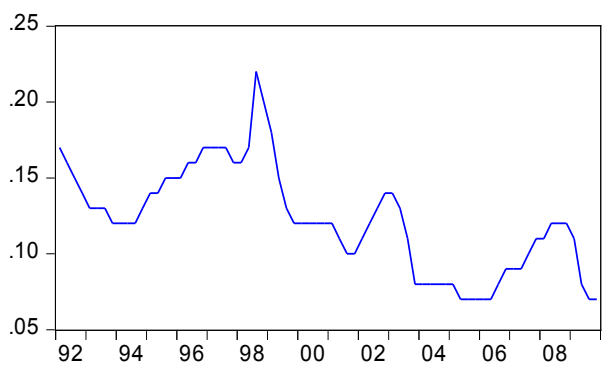

\section{LNREER}

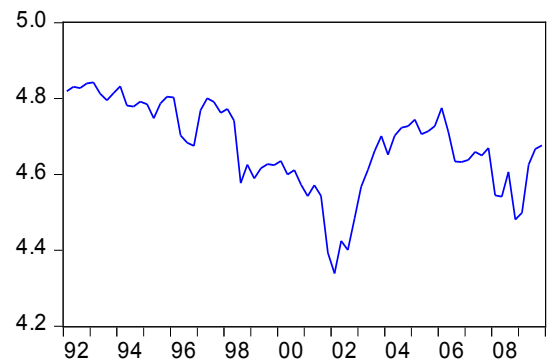

TABLE Al: Unit root tests

\begin{tabular}{|c|c|c|c|c|c|}
\hline Variables & & ADF & $\mathrm{PP}$ & DF-GLS & KPSS \\
\hline \multicolumn{6}{|l|}{ Botswana } \\
\hline Log of Real GDP & BGDP & $\mathrm{I}(\mathrm{l})$ & $\mathrm{I}(\mathrm{l})$ & $\mathrm{I}(0) \star$ & $\mathrm{I}(1)$ \\
\hline Log of M2 & BM2 & $\mathrm{I}(\mathrm{l})$ & $\mathrm{I}(\mathrm{l})$ & $\mathrm{I}(\mathrm{l})$ & $\mathrm{I}(1)$ \\
\hline Log of CPI & $\mathrm{BCPI}$ & $\mathrm{I}(\mathrm{l})$ & $\mathrm{I}(1)$ & $\mathrm{I}(1)$ & $\mathrm{I}(1)$ \\
\hline Log of Nominal Private Sector Credit & $\mathrm{BCRD}$ & $\mathrm{I}(1)$ & $\mathrm{I}(\mathrm{l})$ & $\mathrm{I}(\mathrm{l})$ & $\mathrm{I}(1)$ \\
\hline Log of Real Effective Exchange Rate & BREદR & $\mathrm{I}(\mathrm{l})$ & $\mathrm{I}(\mathrm{l})$ & $\mathrm{I}(\mathrm{l})$ & $\mathrm{I}(\mathrm{l})$ \\
\hline Inflation Rate & BINF & $\mathrm{I}(0)$ & $\mathrm{I}(0)$ & $\mathrm{I}(\mathrm{l})$ & $\mathrm{I}(0)$ \\
\hline Botswana Bank Rate & BBR & $\mathrm{I}(\mathrm{l})$ & $\mathrm{I}(\mathrm{l})$ & $\mathrm{I}(0)$ & $\mathrm{I}(0)$ \\
\hline Real Interest Rate & BRINT & $\mathrm{I}(1)$ & $\mathrm{I}(0)$ & $\mathrm{I}(1)$ & $\mathrm{I}(0)$ \\
\hline Prime Lending Rate & BPRM & $\mathrm{I}(1)$ & $\mathrm{I}(1)$ & $\mathrm{I}(\mathrm{l})$ & $\mathrm{I}(0)$ \\
\hline \multicolumn{6}{|l|}{ Namibia } \\
\hline Log of real GDP & NGDP & $\mathrm{I}(1)$ & $\mathrm{I}(1)$ & $\mathrm{I}(0)$ & $\mathrm{I}(1)$ \\
\hline Log of M2 & NM2 & $\mathrm{I}(1)$ & $\mathrm{I}(1)$ & $\mathrm{I}(0)$ & $\mathrm{I}(1)$ \\
\hline Namibia inflation & NINF & $\mathrm{I}(0)$ & $\mathrm{I}(0)$ & $\mathrm{I}(\mathrm{l})$ & $\mathrm{I}(\mathrm{l})$ \\
\hline Namibia Prime Lending Rate & NPRM & $\mathrm{I}(1)$ & $\mathrm{I}(\mathrm{l})$ & $\mathrm{I}(1)$ & $\mathrm{I}(1)$ \\
\hline Log of Nominal Private Sector Credit & NCRD & $\mathrm{I}(\mathrm{l})$ & $\mathrm{I}(1)$ & $\mathrm{I}(1)$ & $\mathrm{I}(1)$ \\
\hline Real Interest Rate & NRR & $\mathrm{I}(0)$ & $\mathrm{I}(\mathrm{l})$ & $I(0)$ & $\mathrm{I}(0)$ \\
\hline Namibia CPI & NCPI & $\mathrm{I}(\mathrm{l})$ & $\mathrm{I}(1)$ & $\mathrm{I}(1)$ & $\mathrm{I}(1)$ \\
\hline Namibia Bank Rate & NBR & $\mathrm{I}(\mathrm{l})$ & $\mathrm{I}(1)$ & $\mathrm{I}(1)$ & $\mathrm{I}(1)$ \\
\hline \multicolumn{6}{|l|}{ South Africa } \\
\hline South African Repo Rate & SARR & $\mathrm{I}(1)$ & $\mathrm{I}(\mathrm{l})$ & $\mathrm{I}(1)$ & $\mathrm{I}(1)$ \\
\hline Log of Real Effective Exchange Rate & REદR & $\mathrm{I}(\mathrm{l})$ & $\mathrm{I}(\mathrm{l})$ & $\mathrm{I}(1)$ & $\mathrm{I}(\mathrm{l})$ \\
\hline
\end{tabular}

\section{Source: Authors'own calculations}

Notes: Test performed at $5 \%$ significance level, * denotes inclusion of a trend

As TABLE Al indicates, most of the variables appeared to be integrated of the first order, I(1), with the Botswana bank rate, inflation rates, and real interest rates as exceptions since they were found to be stationary. 